University of Nebraska - Lincoln

DigitalCommons@University of Nebraska - Lincoln

\title{
Effects of Prescribed Fire and Herbicide Application on Cattle Grazing and Herbage Production from Yellow Bluestem Pastures
}

S. A. Gunter

USDA, ARS, Southern Plains Range Research Station

R. L. Gillen

Kansas State University

Follow this and additional works at: https://digitalcommons.unl.edu/usdaarsfacpub

Part of the Agricultural Science Commons

Gunter, S. A. and Gillen, R. L., "Effects of Prescribed Fire and Herbicide Application on Cattle Grazing and Herbage Production from Yellow Bluestem Pastures" (2010). Publications from USDA-ARS / UNL Faculty. 854.

https://digitalcommons.unl.edu/usdaarsfacpub/854

This Article is brought to you for free and open access by the U.S. Department of Agriculture: Agricultural Research Service, Lincoln, Nebraska at DigitalCommons@University of Nebraska - Lincoln. It has been accepted for inclusion in Publications from USDA-ARS / UNL Faculty by an authorized administrator of DigitalCommons@University of Nebraska - Lincoln. 


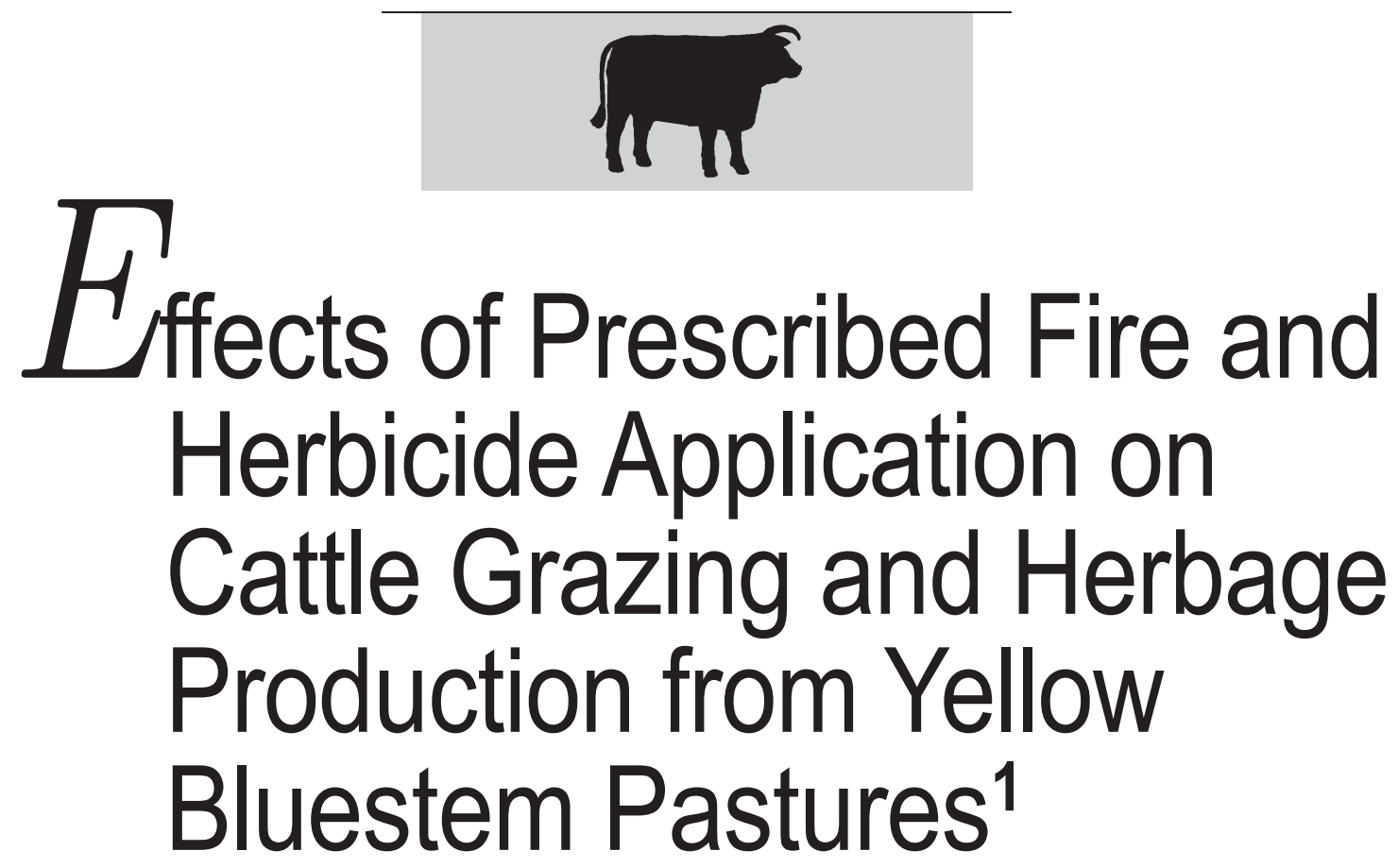

S. A. Gunter, ${ }^{* 2}$ PAS, and R. L. Gillen

*USDA, ARS, Southern Plains Range Research Station, Woodward, OK 73801-5415; and

†Western Kansas Agricultural Research Centers, Kansas State University, Hays 67601-9228

\begin{abstract}
Forage management practices influence the quantity and quality of forage available to grazing cattle. The objectives of this experiment were to determine the effects of prescribed fire or herbicides on the density of forbs, the production and nutritive value of the herbage, and the performance of beef steers grazing Yellow bluestem [Bothriochloa ischaemum (L.) Keng var. ischaemum (Hack.) Celarier and Harlan] pastures. The experiment was conducted in northwestern Oklahoma from 1998 through 2000, and the untreated pastures (control) were not burned or sprayed. The prescribed-fire treatment (PFT) occurred annually between March 27 and April 10. The herbicide treatment (HT) consisted of an annual application of $0.9 \mathrm{~kg}$ of 2,4-dichlorophenoxyacetic acid and $2.8 \mathrm{~g}$ of metsulfuron methyl per

\footnotetext{
${ }^{1}$ Mention of trade names or commercial products in this article is solely for the purpose of providing specific information and does not imply recommendation or endorsement by the USDA.

${ }^{2}$ Corresponding author: Stacey.Gunter@ ars.usda.gov
}

hectare. Compared with the control, forb densities were or tended to be decreased $(P<0.13)$ in PFT and HT pastures only in May and June of 1998; forb densities were not affected $(P \geq 0.45)$ in later months or years. Dry matter production of Yellow bluestem in August was not affected $(P \geq 0.10)$ by treatment, but $C P$ concentration and in vitro OM disappearance were greater $(P \leq 0.05)$ in herbage collected early in the grazing season from PFT pastures than in that from control and HT pastures. Over the 92-d grazing period that started May 30 (initial stocking rate, 1.93 steers/ha), ADG and $B W$ gain per hectare did not differ $(P$ $\geq 0.74$ ) among treatments. Forb control with prescribed fire or the herbicides used in this experiment did not improve the performance of beef cattle grazing Yellow bluestem pastures even though prescribed fire improved forage quality early in the grazing season.

Key words: Bothriochloa ischaemum, cattle, forb, herbicide, prescribed fire

\section{INTRODUCTION}

Yellow bluestem [Bothriochloa ischaemum (L.) Keng var. ischaemum (Hack.) Celarier and Harlan; aka, Old World bluestem] is an important forage for grazing livestock worldwide. This grass is native to Eurasia from the equator north to the $56^{\circ}$ latitude, and it has been naturalized to North America (Celarier and Harlan, 1958). Prescribed fire or herbicide applications are tools for managing Yellow bluestem pastures on the Southern Plains of the United States. The 2 main objectives of burning this grass in the spring are to remove standing dead herbage and decrease weed populations because livestock performance is commonly believed to increase. The primary objective of herbicide application to Yellow bluestem is to decrease weed and brush populations and increase DM production by the grasses, which then can be converted into livestock gains (Fuhlendorf et al., 2009). In Oklahoma, 30\% of Yellow bluestem pastures are treated annually with a broadleaf-selective herbicide to 
increase forage production and, subsequently, livestock production (New, 1997). Studies of herbicide application typically focus on the production of weeds and grasses on small scales and rarely address effects on livestock performance (Thilenius et al., 1975; Fuhlendorf et al., 2009). The application of prescribed fire or herbicides is often based on the appearance of standing herbage mass of dormant forage or annual weed densities in the early spring rather than on the resulting quantitative effects on production characteristics.

Prescribed fire for native rangelands dominated by warm-season grasses has been shown to increase livestock production (Anderson et al., 1970; McCollum et al., 1992), and it is often assumed this response is applicable to monocultures of introduced warm-season grasses such as Yellow bluestem. Nonetheless, Berg (1993) reported that prescribed fire decreased forage production of Yellow bluestem and recommended further study on its effects on livestock performance. The overall effect of prescribed fire relative to livestock performance has not been documented for Yellow bluestem. The objectives of this experiment were to determine the effects of prescribed fire or herbicides on the density and production of forbs, the production and nutritive value of the herbage, and the performance of beef cattle steers grazing Yellow bluestem pastures.

\section{MATERIALS AND METHODS}

\section{Site and Experimental Design}

The study was conducted from 1998 through 2000 at the USDA, ARS, Southern Plains Experimental Range (lat $36^{\circ} 35^{\prime} \mathrm{N}$, long $99^{\circ} 35^{\prime} \mathrm{W}$; elevation $630 \mathrm{~m}$ ) near Fort Supply, Oklahoma. All experimental procedures were approved by the Southern Plains Range Research Station Animal Care and Use Committee.

The regional climate is continental with an average annual precipitation of $576 \mathrm{~mm}$, with $72 \%$ normally falling during the April to September growing season. Average monthly mean temperatures are $2.3^{\circ} \mathrm{C}$ in January and $28^{\circ} \mathrm{C}$ in July. Minimum and maximum recorded temperatures are $-28^{\circ} \mathrm{C}$ and $45^{\circ} \mathrm{C}$, respectively. Soils of the experimental pastures were primarily fine sandy loams of the Grandfield series (Typic Haplustepts) and Hardeman and Grandmore series

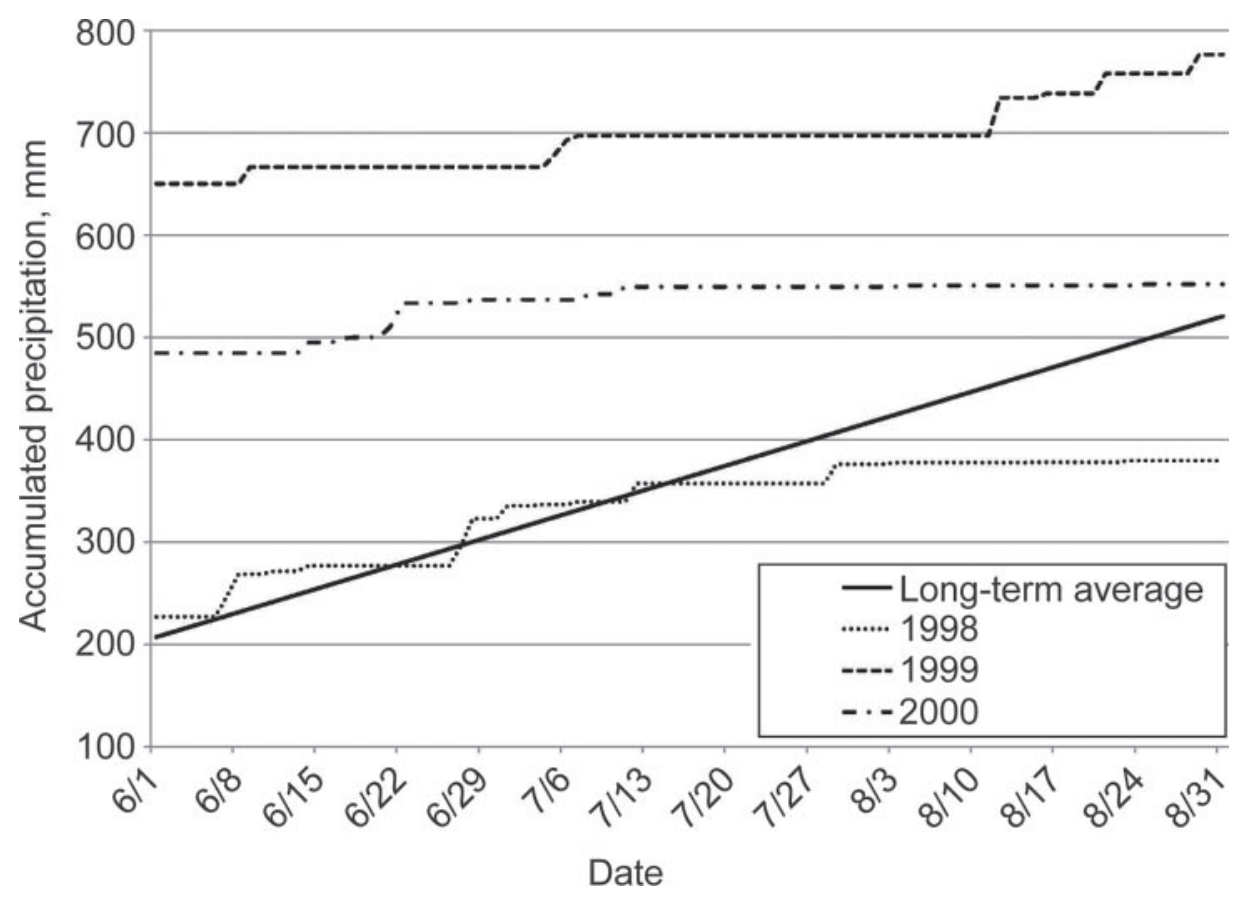

Figure 1. Accumulated precipitation for 1998, 1999, and 2000 between June 1 and August 31 at the Southern Plains Experimental Range near Ft. Supply, Oklahoma.
(Typic Haplustalfs; NRCS, 2008). The pastures used in this experiment supported monocultures of 3 different cultivars of Yellow bluestem: 3 of Plains (Taliaferro et al., 1972), 3 of WW-Spar (Dewald et al., 1985), and 3 of WW-Iron Master (Dewald et al., 1988). All pastures were more than 10 yr old, previous weed control practices were unknown, and pastures ranged in size from 1.7 to 3.6 ha.

The pasture treatments consisted of a control that was not burned or sprayed with a herbicide (control), a burned treatment that was burned between March 27 and April 10 each year (prescribed-fire treatment, PFT), and an herbicide treatment applied between May 20 and 30 annually (HT). Ambient temperatures during burning were 15 to $21^{\circ} \mathrm{C}$, relative humidity was 25 to $35 \%$, wind speeds were 5.3 to $6.7 \mathrm{~m} / \mathrm{s}$, and fires were ignited downwind with drip torches. The herbicide application was a mixture of $0.9 \mathrm{~kg}$ of 2,4-dichlorophenoxyactic acid and $2.8 \mathrm{~g}$ of metsulfuron methyl per hectare. Herbicides were tank mixed with water and applied with a tractor-mounted boom sprayer. The total volume of water and herbicide applied was 93.5 L/ ha. All pastures were fertilized with $56 \mathrm{~kg} / \mathrm{ha}$ of $\mathrm{N}$ from urea (45-0-0) and $39 \mathrm{~kg} /$ ha of $\mathrm{P}$ from triple-phosphate (0-46-0) fertilizers broadcast as prills on approximately April 15 annually. Treatments were blocked by variety of Yellow bluestem. For each treatment, 2 blocks ( $\mathrm{n}=6$ pastures total; 3 of WW-Iron Master and 3 of WW-Spar) were used in 1998 and 3 blocks $(\mathrm{n}=9$ pastures total; 3 of WW-Iron Master, 3 of WW-Spar, and 3 of Plains) were used in 1999 and 2000.

\section{Cattle Measurements}

All pastures were grazed by crossbred yearling beef steers (initial BW $=258 \pm 20 \mathrm{~kg}$; British $\times$ Continental) at a stocking density of 1.93 steers/ha. As recommended by Berg (1993), grazing started on May 30 and ended on August 30, resulting in a 92-d grazing period. Experimental herds consisted of 3 to 7 steers, 
depending on pasture size. Because of limited precipitation in 1998 (Figure 1), stocking density was decreased from 1.93 to 1.29 steers/ha after the first $30 \mathrm{~d}$ of grazing. Steers were not given any supplemental feed during the experiment but had ad libitum access to 23-kg blocks of plain salt. Steer BW were collected in the morning after fasting overnight (17 h) without feed or water on May 30 , June 30, July 28, and August 30, annually, and BW were recorded.

\section{Herbage Measurements}

Each May, 5 exclosures $(4.9 \times 4.9$ $\mathrm{m})$ consisting of wire panels with a $15-\mathrm{cm}$ mesh were placed randomly in each pasture before grazing; exclosures were moved to new locations annually. In mid August, herbage production by Yellow bluestem and forbs was determined by hand clipping 2 quadrats $(0.29 \times 0.61 \mathrm{~m})$ to the ground level inside each exclosure, and residual herbage was determined by hand clipping 2 quadrats outside each exclosure. Herbage samples were dried at $60^{\circ} \mathrm{C}$ for $5 \mathrm{~d}$ before weighing. Densities of all forbs were counted with $0.25-\mathrm{m}^{2}$ quadrats (40/pasture) in May, early June (approximately 3 wk after herbicide application), and in mid August. Forb density data were converted to plants per square meter by multiplying the raw data by 4 . Herbage mass samples for chemical composition analysis were collected on each cattle weigh date by paced transects and clipping current growth for the year (20 to $30 \mathrm{~g} \mathrm{DM}$ ) of Yellow bluestem plants at 6 points in each pasture. Herbage mass samples were amalgamated within pasture, oven dried at $60^{\circ} \mathrm{C}$ for $72 \mathrm{~h}$, uniformly ground to pass a 1-mm screen, and analyzed for total N (Bremner and Breitenbeck, 1983) and in vitro OM disappearance (IVOMD; Tilley and Terry, 1963 as modified by White et al., 1981). Nitrogen concentration was multiplied by 6.25 to estimate CP. The IVOMD:CP ratio was calculated by dividing the percentage of IVOMD by the percentage of $\mathrm{CP}$ on a $\mathrm{DM}$ basis as described by Gunter et al. (1995a).

\section{Statistical Analysis}

Pasture means of forb densities, CP and IVOMD concentrations in the herbage mass, and the IVOMD:CP ratio were analyzed with an ANOVA using the Mixed Models procedure in SAS (SAS Institute Inc., Cary, NC) as a split-plot in time (month). The fixed effects in the model were treatment, years, months, and their interactions; the random effect was grass variety. Steer BW, ADG by period and the entire grazing season, total BW gain, standing herbage mass (inside and outside the exclosures), and BW gain per hectare were analyzed with an ANOVA using the Mixed Models procedure in SAS. The fixed effects in the model for animal performance variables and standing herbage mass were treatment, years, and their interaction; the random effect was grass variety. In all analyses, year was considered a fixed effect because of the small number of years sampled. If a significant $F$-test was detected $(P \leq 0.05)$, least squares means were separated using predicted differences (Steel and Torrie, 1980).

\section{RESULTS AND DISCUSSION}

\section{Climate and Precipitation}

Winter precipitation at the Southern Plains Experimental Range weather station $(2.0 \mathrm{~km}$ southwest of pastures) was above the long-term average $(207 \mathrm{~mm}$; January to May from 1988 to 1997) for all years (227, 650, and $485 \mathrm{~mm}$ for 1998, 1999, and 2000, respectively; Figure 1). Precipitation from June 1 to August 31, the primary production period for Yellow bluestem, was quite different among years. In 1998, pre-grazingseason (winter) precipitation was near normal; however, precipitation during the grazing season (June 1 through August 31$)$ was $48 \%(153 \mathrm{~mm})$ of the long-term average $(317 \mathrm{~mm})$. Because of the ability of Yellow bluestem to respond quickly to precipitation
(Philipp et al., 2007), adequate precipitation at the end of June and early July of 1998 stimulated new forage growth (Figure 1). In contrast, during 1999 and 2000, pre-grazing-season precipitation was $314 \%(650 \mathrm{~mm})$ and $221 \%$ ( $485 \mathrm{~mm}$ ), respectively, of the long-term average $(207 \mathrm{~mm})$. June 1 to August 31 precipitation was below average $(232 \mathrm{~mm})$ in $1999(126 \mathrm{~mm})$ and $2000(94 \mathrm{~mm})$. However, because of the above-average precipitation the previous winters of 1999 and 2000, soil moisture seemed to remain sufficient for forage production.

\section{Pasture Measurements}

Forb density interacted $(P<0.01)$ by treatments, months, and years. In May 1998, forb density in the control pastures $\left(18\right.$ plants $\left./ \mathrm{m}^{2}\right)$ differed $(P$ $<0.01)$ from that in the HT $(22.6$ plants $/ \mathrm{m}^{2}$ ) and PFT (6.2 plants/ $\left.\mathrm{m}^{2}\right)$ pastures. The HT treatment was not applied until May 20 in 1998, which was $17 \mathrm{~d}$ after the forb densities for May had been counted (May 3); however, the PFT treatment had been applied on April 10. In May of 1999 and 2000, forb densities did not differ $(P>0.05)$ among the treatments. Also, forb densities in May of 1998 were less $(P<0.01)$ than in $1999($ control $=2.0, \mathrm{PFT}=1.2, \mathrm{HT}$ $=1.1$ plants $\left./ \mathrm{m}^{2}\right)$ or 2000 (control $=$ $0.6, \mathrm{PFT}=0.5, \mathrm{HT}=0.8$ plants $/$ $\left.\mathrm{m}^{2}\right)$. In June 1998, forb densities in control pastures $\left(3.5\right.$ plant $\left./ \mathrm{m}^{2}\right)$ were greater $(P \leq 0.02)$ than those in HT pastures $\left(0.01 \mathrm{plant} / \mathrm{m}^{2}\right)$, with those in PFT pastures $\left(1.2 \mathrm{plant} / \mathrm{m}^{2}\right)$ being intermediate $(P \geq 0.13)$. No differences $(P \geq 0.67)$ were noted in forb densities among treatments or years (range, $<0.05-1.4$ plants $/ \mathrm{m}^{2}$; data not presented).

The seasonal decrease in forb densities cannot be attributed to the dry conditions noted during 1998 because forbs also declined in 1999 and 2000, when precipitation was more favorable. Forbs were identified by species; they were dominated by annual species ( $87 \%$ of all forbs). Major forbs included horseweed [Conyza canadensis (L.) Cronq.], Texas toadflax [Linaria 
canadensis (L.) Dum.], clasping Venus' looking-glass [Triodanis perfoliata (L.) Nieuw.], and carpetweed [Mollugo verticillata (L.)]. This seasonal decrease in forbs in Yellow bluestem pastures is not surprising because Bodine et al. (2001) reported that forbs were present in measurable quantities only during May in unburned plots of Plains Yellow bluestem but were almost devoid by late summer. This seasonal response is evidence of the competitive ability of well-managed Yellow bluestem to capture nutrients from the soil, putting competing forbs at a disadvantage (Springer, 2007). Furthermore, Gunter et al. (1995b) reported that annual forbs in a Plains Yellow bluestem pasture located near Bessie, Oklahoma (located $145 \mathrm{~km}$ south of our experimental site), managed with no burning or herbicides decreased from $19 \%$ of the total stand in May to trace levels $(<0.5 \%)$ by October. In 2 experiments examining broadleaf weed control on mixed-grass or tallgrass prairies, forb populations were more strongly correlated with year than with herbicide application (Fuhlendorf et al., 2002, 2009). Thus, results of the present and previous experiments suggest little long-term benefits of herbicide use for controlling broadleaf weeds in Yellow bluestem pastures because the majority of weeds are annuals and will decrease because of antagonism from the Yellow bluestem.

Production of DM by Yellow bluestem pastures inside the exclosures, where grazing was excluded, did not differ among treatments $(P=$ 0.89; control $=6,340, \mathrm{PFT}=6,130$, $\mathrm{HT}=6,370 \mathrm{~kg} / \mathrm{ha} ; \mathrm{SE}=424)$. Yellow bluestem DM production, where grazing occurred, outside the exclosures, also did not differ $(P \geq 0.11$; control $=4,970, \mathrm{PFT}=5,210, \mathrm{HT}=3,700$ $\mathrm{kg} / \mathrm{ha} ; \mathrm{SE}=710$ ). The herbage DM production of Yellow bluestems was affected $(P<0.01)$ by years, both inside and outside the exclosures. In 1998, standing herbage DM production of Yellow bluestems inside the exclosures $(4,290 \mathrm{~kg} / \mathrm{ha})$ was less $(P$ $<0.01)$ and did not differ $(P=0.23)$ outside the exclosure $(3,450 \mathrm{~kg} / \mathrm{ha})$ compared with 1999 (6,710 and 4,380 $\mathrm{kg} /$ ha, respectively); however, quantities in $2000(7,840$ and $6,050 \mathrm{~kg} / \mathrm{ha}$, respectively) were both greater $(P<$ 0.04) than in 1999.

The amount of standing herbage DM in the grazed areas estimated in mid August indicates that herbage DM allowance was likely not limiting herbage DMI; the herbage DM allowance was always greater than 1,344 $\mathrm{kg} /$ steer as suggested by JohnstoneWallace and Kennedy (1944) as the point at which allowance limits DMI. Regarding the HT treatment, Fuhlendorf et al. (2009) also found no effect of herbicide treatments on the DM production by perennial warm-season grasses in mixed-grass prairie in western Oklahoma. For the PFT treatment, the current results differ from those reported by Berg (1993), who noted that burning decreased forage DM production of Iron Master Yellow bluestem an average of $16 \%$ (range, 6 to $30 \%$ ). One major difference between these 2 experiments is that the study by Berg (1993) was conducted on loamy soils compared with the sandy loam soils of the current experimental location. In addition, Berg (1993) selected an earlier average date to apply fire (March 24) in 3 of the 4 yr of the experiment at Woodward, Oklahoma (581 m elevation); in the last year, Berg (1993) burned on April 6 , and herbage DM production did not differ compared with nonburned sites. In an experiment in northcentral Oklahoma (293 m elevation), annual DM production of Plains Yellow bluestem was not affected by prescribed fire (April 4; Bodine et al., 2001) when applied later in the spring as in the last year of the experiment by Berg (1993). Research conducted on tallgrass prairie has shown that early spring burning decreases herbage DM production compared with unburned prairies, whereas burning in late spring has no effect on herbage DM production (Anderson et al., 1970; Towne and Owensby, 1984). Some researchers have suggested that the effect of prescribed fire and its timing on herbage DM production is related to soil texture and water- holding capacity. Soils with a greater water-holding capacity may be less susceptible to decreased herbage DM production when burning is applied in the early spring (Engle and Bidwell, 2001). In the present experiment, the water-holding capacities of the Grandfield and Grandmore soils were both $3.3 \mathrm{~cm}$ in the top $25 \mathrm{~cm}$ (NRCS, 2008); the Carey and Quinlan soils at the site used by Berg (1993) had water-holding capacities that were $39 \%$ $(4.5 \mathrm{~cm})$ and $26 \%(4.1 \mathrm{~cm})$ greater in the top $25 \mathrm{~cm}$ than those at our site (NRCS, 2008). Hence, the suggestion that the effect on herbage DM production is related to water-holding capacity of the soil does not seem to hold true in this instance (Engle and Bidwell, 2001).

\section{Herbage Quality}

Crude protein concentration, IVOMD, and the ratio of IVOMD to $\mathrm{CP}$ concentrations in forage samples interacted $(P<0.01)$ among treatments, months, and years. However, data are compared among treatments and years within months in the following discussions.

In May of all years, CP concentration in the PFT pastures was greater $(P<0.01)$ than that in the control pastures, but the HT pastures did not differ $(P \geq 0.17)$ from the control pastures (Table 1). Also, CP concentration in May of 1998 was less $(P<$ 0.01) than that in 1999 for all treatments, and in 2000 the CP concentration was intermediate $(P \leq 0.05)$ to 1998 and 1999. The HT pastures in May 2000 did not differ $(P=0.23)$ from those in May 1999. In June, CP concentration of PFT or HT pastures did not differ $(P \geq 0.08)$ from that of the control pasture during any year. For the control and HT pastures in June, CP concentration was lower $(P$ $<0.05)$ in 1998 than in 1999 or 2000, but no differences $(P>0.05)$ were noted among years in the PFT pastures. In July and August of 1998, CP concentration was greater $(P \leq 0.05)$ in PFT and HT pastures than in the control pastures, but CP concentrations did not differ $(P>0.28)$ among 


\section{Table 1. Least squares means of CP concentration (\% of DM) in herbage mass collected from Yellow bluestem from pastures as affected by prescribed fire or herbicide treatment ${ }^{1}$ in northwestern Oklahoma}

\begin{tabular}{lcccc} 
Month and year & Control & PFT & HT & SE $^{2}$ \\
\hline May & & & & \\
1998 & $10.0^{\mathrm{a}, \mathrm{d}}$ & $12.7^{\mathrm{b}, \mathrm{d}}$ & $10.2^{\mathrm{a}, \mathrm{d}}$ & 0.47 \\
1999 & $13.2^{\mathrm{a}, \mathrm{e}}$ & $15.0^{\mathrm{b}, \mathrm{e}}$ & $13.5^{\mathrm{a}, \mathrm{e}}$ & 0.46 \\
2000 & $12.2^{\mathrm{a}, \mathrm{f}}$ & $13.9^{\mathrm{b}, \mathrm{f}}$ & $12.9^{\mathrm{a}, \mathrm{e}}$ & 0.39 \\
June & & & & \\
1998 & $6.3^{\mathrm{d}}$ & 6.8 & $6.2^{\mathrm{d}}$ & 0.47 \\
1999 & $7.6^{\mathrm{e}}$ & 8.2 & $8.5^{\mathrm{e}}$ & 0.39 \\
2000 & $8.3^{\mathrm{e}}$ & 9.0 & $8.2^{\mathrm{e}}$ & 0.39 \\
July & & & & \\
1998 & $8.3^{\mathrm{a}, \mathrm{d}}$ & $11.5^{\mathrm{b}, \mathrm{d}}$ & $10.6^{\mathrm{b}, \mathrm{d}}$ & 0.47 \\
1999 & $4.3^{\mathrm{e}}$ & $4.3^{\mathrm{e}}$ & $4.9^{\mathrm{e}}$ & 0.39 \\
2000 & $5.6^{\mathrm{f}}$ & $5.3^{\mathrm{e}}$ & $5.5^{\mathrm{e}}$ & 0.39 \\
August & & & & \\
1998 & $6.6^{\mathrm{a}, \mathrm{d}}$ & $9.6^{\mathrm{b}, \mathrm{d}}$ & $8.1^{\mathrm{c}, \mathrm{d}}$ & 0.46 \\
1999 & $3.7^{\mathrm{e}}$ & $3.8^{\mathrm{e}}$ & $3.8^{\mathrm{e}}$ & 0.39 \\
2000 & $4.3^{\mathrm{e}}$ & $3.9^{\mathrm{e}}$ & $4.1^{\mathrm{e}}$ & 0.39 \\
SE & 0.47 & 0.46 & 0.47 & \\
\hline
\end{tabular}

${ }^{a-c}$ Means within rows that do not have common superscripts differ $(P<0.05)$.

${ }^{d-f}$ Means within columns and months that do not have common superscripts differ $(P$ $<0.05)$.

${ }^{1}$ Control $=$ not burned or sprayed with herbicides; PFT $=$ annual prescribed fire between March 27 and April 10; and HT = annual application of a mixture of $0.9 \mathrm{~kg} / \mathrm{ha}$ of 2,4-dichlorophenoxyacetic acid and $2.8 \mathrm{~g} / \mathrm{ha}$ of metsulfuron methyl between May 20 and 30.

${ }^{2} n=2 /$ treatment in 1998, $n=3 /$ treatment in 1999 and 2000.

treatments in 1999 or 2000. For all treatments in July and August, CP concentration was greater $(P>0.05)$ in 1998 than in 1999 or 2000.

In our experiment, herbage $\mathrm{CP}$ concentration was only consistently improved by the PFT treatment in the May to June period (Table 1). The use of prescribed fire on native rangeland has consistently increased $\mathrm{CP}$ concentration of cattle diets in only the early portion of the grazing season (Angell et al., 1986). The increased $\mathrm{CP}$ concentration noted in herbage produced after a prescribed fire in our experiment and other reports is likely the result of increased $\mathrm{N}$ mineralization and decreased nitrogenase activity in the soil (Hobbs and Shimel, 1983) because almost all the herbage $\mathrm{N}$ is volatilized during the fire (Redmann, 1991). From May to August the CP concentration generally decreased. Other research has reported this downward trend in $\mathrm{CP}$ concentra- tion from May to August with Yellow bluestems (Berg, 1993; Gunter et al., 1995b; Philipp et al., 2005). The exception to this trend was in July and August of 1998 because rainfall was more abundant than in 1999 and 2000 (Figure 1). After precipitation or irrigation, Yellow bluestem continues DM accumulation later in the growing season compared with native grasses (Hodges and Bidwell, 1993; Gunter et al., 1995b; Philipp et al., 2007), which results in sharp increases in herbage $\mathrm{CP}$ concentration (Gunter et al., 1995b).

During 1998, IVOMD was greater $(P \leq 0.02)$ in PFT pastures than in control pastures; however, the IVOMD in HT pastures did not differ $(P$ $\geq 0.06$ ) from that in control pastures (Table 2). In June and July of 1999, HT had a greater $(P<0.04)$ IVOMD than did PFT or control pastures. In vitro OM disappearance did not differ $(P \geq 0.23)$ among treatments in $\mathrm{Au}-$ gust 1999 or all of 2000. In May 1999, the control and HT pastures had greater $(P<0.01)$ IVOMD than in 1998 or 2000 , but the PFT pastures in 2000 had a lower $(P<0.03)$ IVOMD than in 1998 or 1999. In July and August across treatments, IVOMD was greater $(P<0.05)$ in 1998 than in 1999 or 2000.

Prescribed fire has generally increased in vitro digestibility of herbage in the early parts of the grazing season, but the benefits generally diminish as the season advances (Angell et al., 1986). Although Bodine et al. (2001) did not measure IVOMD, they reported that burning Plains Yellow bluestem did not affect the leaf:stem ratio of the standing herbage mass. Because the leaves of grasses in the Bothriochloa genus have greater digestibility than the stems (White and Dewald, 1988, 1996), the lack of change in the leaf:stem ratio with prescribed fire suggests a minimal effect of burning on its digestibility. Only a single experiment was located that reported the effect of herbicide application on the ruminally digestible energy values of the dietary herbage. Thilenius et al. (1975) reported that total VFA concentrations in the ruminal fluid of cattle grazing subalpine rangeland in Wyoming did not differ between pastures sprayed with $0.9 \mathrm{~kg}$ of 2,4-dichlorophenoxyacetic acid per hectare ( $10 \%$ forbs) and nonsprayed pastures ( $79 \%$ forbs), suggesting no difference in ruminal VFA production. In the present study, IVOMD generally decreased with the advancing grazing season, which is in agreement with other reports (White and Dewald, 1996; Gunter et al., 1997; Philipp et al., 2005). The increase noted for IVOMD in July 1998 was associated with increased precipitation in June (Figure 1). Gunter et al. (1995b) reported a similar increase in IVOMD for esophageal masticate samples collected from Plains Yellow bluestem after significant precipitation occurred 2 wk before sampling in late summer.

In May and June, no differences $(P$ $>0.11)$ were detected among treatments or years (Table 3). In July, forages samples collected in 1998 
from the control pastures indicated a greater $(P<0.05)$ IVOMD:CP ratio compared with the PFT and HT pastures; no differences $(P>0.05)$ were detected in IVOMD:CP ratios among treatments in July of 1999 or 2000. In August, forage samples collected in 1998 and 2000 from the control pastures had a greater $(P$ $<0.05)$ IVOMD:CP ratio than did samples from the PFT and HT pastures, but no differences $(P>0.05)$ were detected in 1999. In July and August, forage samples collected in 1999 or 2000 had a greater $(P<0.05)$ IVOMD:CP ratio than did samples collected in 1998.

A ratio of IVOMD:CP between 4.0 and 4.5 indicates a balance of ruminal-available $\mathrm{N}$ to ruminal-available energy in cattle diets (Hogan and Weston, 1970; Gunter et al., 1995a). Based on this premise, when this ratio is greater than 4.5, a supplement high in ruminally degradable $\mathrm{N}$ would be the most efficacious choice for stimulating microbial protein production in the rumen. In contrast, when dietary $\mathrm{N}$ is not limiting (ratio $<4.5$ ), a highstarch or digestible fiber supplement would be more beneficial (Nocek and Russell, 1988). The ratio of IVOMD:CP was 5.0 or greater for all sampling dates. Based on the suggestion of Gunter et al. (1995a), a supplement high in ruminally degradable $\mathrm{N}$, such as cottonseed (Gossypium hirsutum) meal, would have increased ADG during the experiment, especially after June 1. Moore et al. (1999) examined the ratio of IVOMD:CP in forage-based diets with a wide range of qualities and various supplement types offered (protein and energy type supplements). These researchers found that when the IVOMD:CP ratio was greater than 7 , supplementation generally increased forage DMI (Moore et

\section{Table 2. Least squares means of in vitro OM disappearance concentration (\%) in herbage mass collected from Yellow bluestem pastures as affected by prescribed fire or herbicide treatment ${ }^{1}$ in northwestern Oklahoma}

\begin{tabular}{lllll} 
Month and year & Control & PFT & HT & SE $^{2}$ \\
\hline May & & & & \\
1998 & $63.7^{\mathrm{a}, \mathrm{d}}$ & $72.9^{\mathrm{b}, \mathrm{d}}$ & $62.4^{\mathrm{a}, \mathrm{d}}$ & 1.36 \\
1999 & $71.0^{\mathrm{ab}, \mathrm{e}}$ & $73.5^{\mathrm{b}, \mathrm{d}}$ & $70.8^{\mathrm{a}, \mathrm{e}}$ & 1.18 \\
2000 & $66.6^{\mathrm{f}}$ & $69.7^{\mathrm{e}}$ & $66.3^{\mathrm{f}}$ & 1.18 \\
June & & & & \\
1998 & $58.1^{\mathrm{a}}$ & $62.1^{\mathrm{b}}$ & $55.1^{\mathrm{a}, \mathrm{d}}$ & 1.36 \\
1999 & $60.0^{\mathrm{a}}$ & $60.1^{\mathrm{a}}$ & $63.4^{\mathrm{b}, \mathrm{e}}$ & 1.18 \\
2000 & 60.9 & 61.7 & $60.7^{\mathrm{f}}$ & 1.18 \\
July & & & & \\
1998 & $60.4^{\mathrm{a}, \mathrm{d}}$ & $64.7^{\mathrm{b}, \mathrm{d}}$ & $61.2^{\mathrm{a}, \mathrm{d}}$ & 1.36 \\
1999 & $51.0^{\mathrm{a}, \mathrm{e}}$ & $50.8^{\mathrm{a}, \mathrm{e}}$ & $53.5^{\mathrm{c}, \mathrm{e}}$ & 1.18 \\
2000 & $53.4^{\mathrm{e}}$ & $53.6^{\mathrm{e}}$ & $53.7^{\mathrm{e}}$ & 1.18 \\
August & & & & \\
1998 & $57.3^{\mathrm{a}, \mathrm{d}}$ & $61.7^{\mathrm{b}, \mathrm{d}}$ & $58.0^{\mathrm{a}, \mathrm{d}}$ & 1.36 \\
1999 & $50.1^{\mathrm{e}}$ & $48.6^{\mathrm{e}}$ & $50.6^{\mathrm{e}}$ & 1.18 \\
2000 & $49.8^{\mathrm{e}}$ & $50.3^{\mathrm{e}}$ & $50.2^{\mathrm{e}}$ & 1.18 \\
SE & 1.36 & 1.34 & 1.35 & \\
\hline
\end{tabular}

${ }^{a-c}$ Means within rows that do not have common superscripts differ $(P<0.05)$.

${ }^{d-f}$ Means within columns and months that do not have common superscripts differ $(P$ $<0.05)$.

${ }^{1}$ Control $=$ not burned or sprayed with herbicides; $\mathrm{PFT}=$ annual prescribed fire between March 27 and April 10; and HT = annual application of a mixture of $0.9 \mathrm{~kg} / \mathrm{ha}$ of 2,4-dichlorophenoxyacetic acid and $2.8 \mathrm{~g} / \mathrm{ha}$ of metsulfuron methyl between May 20 and 30 .

${ }^{2} n=2 /$ treatment in 1998, $n=3 /$ treatment in 1999 and 2000. al., 1999). With the recommendation of Gunter et al. (1995a) for ruminally degradable N supplementation when the ratio of IVOMD:CP is greater than 4.5, their model predicts an increase in microbial protein production in the rumen. For the herbage samples collected in May, no IVOMD:CP ratios were greater than 7 (Table 3). With sampling periods after May, $73 \%$ of the ratios were 7 or greater. Supplementation of cattle grazing Yellow bluestem pastures with a ruminally degradable $\mathrm{N}$ source during late June through August would probably increase forage DMI compared with nonsupplemented cattle; supplementation would probably be expressed in increased ADG.

\section{Cattle Measurements}

Year and treatment did not $(P \geq$ 0.09) interact for steer BW or ADG between June 30 and August 31, total $\mathrm{BW}$ gain, and BW gain per hectare (Table 4); however, ADG for the period from May 30 to June 30 was affected $(P=0.03)$ by the interaction between treatment and year (Figure 2). In 1998 and 1999, ADG from May 30 to June 30 did not differ $(P>$ $0.10)$ by treatment, but in 2000 , steers grazing the control and HT pastures had greater $(P<0.04)$ ADG than did steers grazing the PFT pastures. Steers grazing the control pastures had a greater $(P<0.01)$ ADG in June in 2000 than in 1998 or 1999. For all treatments in 1998, steers had lower $(P<0.01)$ ADG than in 1999 and 2000. Average daily gain was not affected by treatment $(P \geq 0.67)$ for the periods of July 1 to July 28, July 29 to August 30, and May 30 to August 30 (Table 4). Steer BW was not affected $(P \geq 0.57)$ by treatment within any month; steer BW did differ by year $(P \leq 0.05$; data not shown) because of differences in initial starting BW. Likewise, ADG in the periods from July 1 to August 30 or from May 30 to August 30, total BW gain, and BW gain per hectare were not affected $(P \geq 0.74)$ by treatment. However, ADG from May 30 to August 30 and BW gain per hectare did 


\begin{tabular}{|c|c|c|c|c|}
\hline Month/year & Control & PFT & HT & $\mathrm{SE}^{2}$ \\
\hline \multicolumn{5}{|l|}{ May } \\
\hline 1998 & 6.5 & 5.9 & 6.4 & 0.43 \\
\hline 1999 & 5.5 & 5.0 & 5.2 & 0.35 \\
\hline 2000 & 5.7 & 5.0 & 5.2 & 0.35 \\
\hline \multicolumn{5}{|l|}{ June } \\
\hline 1998 & 9.3 & 9.2 & 9.0 & 0.43 \\
\hline 1999 & 8.1 & 7.3 & 7.5 & 0.35 \\
\hline 2000 & 7.4 & 6.9 & 7.5 & 0.35 \\
\hline \multicolumn{5}{|l|}{ July } \\
\hline 1998 & $7.5^{\mathrm{a}, \mathrm{d}}$ & $5.8^{b, d}$ & $5.9^{b, d}$ & 0.43 \\
\hline 1999 & $12.0^{\mathrm{e}}$ & $11.8^{\mathrm{e}}$ & $11.1^{\mathrm{e}}$ & 0.35 \\
\hline 2000 & $9.6^{d}$ & $10.0^{\mathrm{e}}$ & $9.9^{e}$ & 0.35 \\
\hline \multicolumn{5}{|l|}{ August } \\
\hline 1998 & $8.7^{\mathrm{a}, \mathrm{d}}$ & $6.6^{b, d}$ & $7.3^{b, d}$ & 0.43 \\
\hline 1999 & $13.5^{\mathrm{e}}$ & $12.7^{\mathrm{e}}$ & $13.3^{e}$ & 0.35 \\
\hline 2000 & $11.9^{\mathrm{a}, \mathrm{e}}$ & $13.1^{\mathrm{b}, \mathrm{e}}$ & $12.3^{\mathrm{ab}, \mathrm{e}}$ & 0.35 \\
\hline SE & 0.43 & 0.42 & 0.42 & \\
\hline
\end{tabular}

${ }^{a-c}$ Means within rows that do not have common superscripts differ $(P<0.05)$.

${ }^{d-f}$ Means within columns and months that do not have common superscripts differ $(P$ $<0.05)$.

${ }^{1}$ Control $=$ not burned or sprayed with herbicides; PFT $=$ annual prescribed fire between March 27 and April 10; and HT = annual application of a mixture of $0.9 \mathrm{~kg} / \mathrm{ha}$ of 2,4-dichlorophenoxyacetic acid and $2.8 \mathrm{~g} / \mathrm{ha}$ of metsulfuron methyl between May 20 and 30 .

${ }^{2} \mathrm{n}=2$ /treatment in 1998, $\mathrm{n}=3$ /treatment in 1999 and 2000. ing to have a positive effect on steer performance in our experiment. First, standing dead vegetation was insufficient to augment any potential advantage of burning. Second, grazing may not have started early enough in the spring to fully capture any potential benefits of burning because these effects are typically greatest in the early growing season (Angell et al., 1986; McCollum et al., 1992). In the area of Oklahoma where this experiment was conducted, stocking of native mixed-grass pastures normally occurs 3 to 4 wk before Yellow bluestem is recommended to be stocked (McIlvain and Shoop, 1962; Shoop and McIlvain, 1971; Berg, 1993). If this second reason is correct, burning of Yellow bluestem would have had limited potential to increase steer BW gain because grazing could not have started more than 7 to $14 \mathrm{~d}$ earlier if the initial stocking densities were to be maintained over the entire season. As discussed previously, using prescribed fire earlier in the spring to initiate grazing at an earlier date may potentially result in decreased total herbage DM production (Berg, 1993). In experiments conducted in Woodward, Oklahoma, production by Iron Master Yellow bluestem and Cauca- differ $(P \leq 0.03)$ by year (data not shown) because of differences associated with the random effects of years. Years did not differ for ADG from July 1 to July 28 or in total BW gain per hectare $(P \geq 0.23)$. Because BW gain per steer and stocking densities did not differ among treatments, BW gain per hectare also was not affected $(P=0.78)$ by treatment (Table 4$)$.

Others have reported ADG ranging from 0.6 to $1.3 \mathrm{~kg}$ for steers grazing Yellow bluestem pastures (Berg and Sims, 1995; Teague et al., 1996; Ackerman et al., 2001), which is similar to the range in ADG of 0.95 to $1.09 \mathrm{~kg}$ recorded in the present experiment. The burning of native grasslands dominated by warm-season grasses has generally increased steer BW gains, especially early in the growing season (Anderson et al., 1970; Angell et al., 1986; McCollum et al., 1992). There are at least 2 possible explanations for the failure of burn-
Table 4. Least squares means of BW and performance of steers grazing Yellow bluestem pastures as affected by prescribed fire or herbicide treatment ${ }^{1}$ in northwestern Oklahoma

\begin{tabular}{lccccc} 
Item and month & Control & PFT & HT & SE $^{2}$ & $P$-value \\
\hline BW, kg & & & & & \\
May 30 & 259 & 261 & 260 & 3.8 & 0.59 \\
June 30 & 297 & 297 & 297 & 3.8 & 0.97 \\
July 28 & 329 & 329 & 330 & 9.8 & 0.98 \\
August 30 & 356 & 356 & 359 & 15.9 & 0.74 \\
ADG, kg & 1.4 & 1.4 & 1.4 & 0.11 & 0.94 \\
May 30 to June 30 & 1.0 & 0.9 & 1.0 & 0.21 & 0.78 \\
July 1 to August 30 & 1.1 & 1.0 & 1.1 & 0.16 & 0.70 \\
May 30 to August 30 & 100 & 98 & 102 & 6.1 & 0.71 \\
Total BW gain, kg/steer & 204 & 203 & 211 & 15.3 & 0.78 \\
BW gain/ha, kg &
\end{tabular}

${ }^{1}$ Control $=$ not burned or sprayed with herbicides; $\mathrm{PFT}=$ annual prescribed fire between March 27 and April 10; and HT = annual application of a mixture of $0.9 \mathrm{~kg} / \mathrm{ha}$ of 2,4-dichlorophenoxyacetic acid and $2.8 \mathrm{~g} / \mathrm{ha}$ of metsulfuron methyl between May 20 and 30 .

${ }^{2} n=8 /$ treatment.

${ }^{3}$ May BW was used a covariate $(P<0.01)$. 


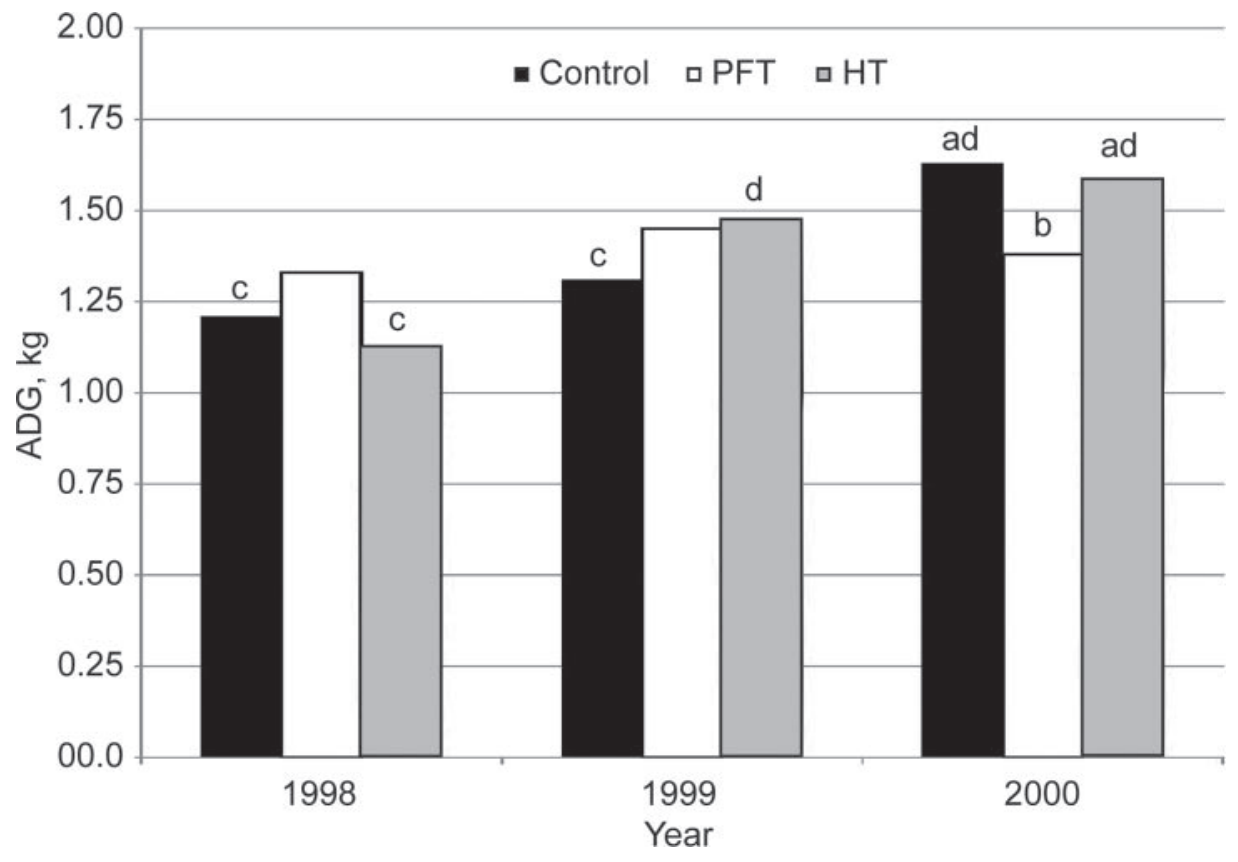

Figure 2. Average daily gain by steers grazing Yellow bluestem pastures between May 30 and June 30 in 1998 ( $\mathrm{n}=2$ /treatment), 1999 ( $\mathrm{n}=3$ /treatment), and 2000 ( $\mathrm{n}=3$ / treatment) at the Southern Plains Experimental Range near Ft. Supply, Oklahoma. Treatments were as follows: Control = not burned or sprayed with herbicides, PFT = annual prescribed fire between March 27 and April 10, and HT = annual application of a mixture of $0.9 \mathrm{~kg} / \mathrm{ha}$ of 2,4-dichlorophenoxyacetic acid and $2.8 \mathrm{~g} / \mathrm{ha}$ of metsulfuron methyl between May 20 and 30. ${ }^{a, b}$ Least squares means within years that do not have common letters differ $(P<0.05)$. ${ }^{\mathrm{c}, \mathrm{d}}$ Least squares means within treatments that do not have common letters differ $(P<0.05)$.

sian bluestem [Bothriochloa caucasica (Trin.) C.E. Hubb.] was only between 1,150 and $1,280 \mathrm{~kg} /$ ha of leaf material during May (White and Dewald, 1996). This rate of leaf production during May, assuming a 50\% forage wastage that is normally associated with continuous stocking, would not produce enough herbage per hectare to carry $260-\mathrm{kg}$ steers at the 1.93 steers/ha stocking rate. Hence, starting the grazing season earlier on Yellow bluestem at the present stocking rate does not seem to be a practical option.

The response of livestock performance to forb control with herbicides is seldom reported. As in our experiment, livestock performance was not influenced by herbicide application on rangelands like those found in western Oklahoma (Fuhlendorf et al., 2009) or in Wyoming (Thilenius et al., 1975). Forbs were a greater proportion of the vegetation in these rangeland studies than in ours $(23 \%$ of canopy cover in western Oklahoma,
$75 \%$ of the herbage DM production in Wyoming). For cattle to benefit from herbicide application, 1 of 2 things probably needs to occur. First, the forbs controlled by the herbicide application should not to be plants used by the cattle. Research with cattle grazing Yellow bluestem pasture has shown that between 5 and $49 \%$ of the total dietary DM can be from forbs (Gunter et al., 1995b). Chemical analysis of the forbs has shown them to be potential sources of high-quality dietary herbage. Gunter et al. (1995b) reported that Russian thistle (Salsola iberica) can contain between 27 and $28 \%$ CP, which can contribute significantly to diet quality at the percentages of the diet reported. Second, if forbs are removed from nonequilibrium grasslands, the remaining grass will need to replace forbs in the diets through increased DM production. Weed control in grass communities with herbicides on small plots has increased the production of grasses (Morrow and McCarthy, 1976; Rice and Stritzke, 1989). The extrapolation of small-plot data to grasslands violates our understanding of scaling in grassland ecosystems (Fuhlendorf and Smeins, 1996, 1999). Pastures for small-plot studies (smaller scale) are normally selected based on their uniformity to minimize plot-to-plot variation. In larger-scale research, treatments are applied over areas with a high degree of temporal variation across multi-landscapes. Large-scale research on nonequilibrium rangeland has indicated no increase in grass DM production as a result of herbicide treatment (Fuhlendorf et al., 2002, 2009), and this is also evidenced by our results from annual herbage DM estimates inside and outside the exclosures (Table 2).

\section{IMPLICATIONS}

The PFT and HT treatments had similar effects on forbs in this experiment; there was no value of forb control regarding animal performance. Yellow bluestem is competitive with forbs as evidenced by the seasonal decrease in forb densities in the control treatment. If forb populations are dominated by annuals, little treatment carryover can be expected from year to year. This fact decreases the value of forb-control treatments even further because treatment costs cannot be annualized over years. Berg (1993) recommended that prescribed fire not be used with Yellow bluestem unless there was a need to remove excessive dormant forage or to control a specific plant because he observed that burning decreased forage production. Results from our experiment suggest that annual prescribed fire or herbicide application is not beneficial to the management of Yellow bluestem. Appropriate fertilization and proper grazing management seem to be the most effective methods to manage Yellow bluestem.

\section{LITERATURE CITED}

Ackerman, C. J., T. H. Purvis, G. W. Horn, S. I. Paisley, R. R. Reuter, and T. N. Bodine. 2001. Performance of light vs heavy steers 
grazing Plains Old World bluestem at three stocking rates. J. Anim. Sci. 79:493.

Anderson, K. L., E. F. Smith, and C. E. Owensby. 1970. Burning bluestem range. J. Range Manage. 23:81.

Angell, R. F., J. W. Stuth, and D. L. Drawe. 1986. Diets and liveweight changes of cattle grazing fall burned gulf cordgrass. J. Range Manage. 39:233.

Berg, W. A. 1993. Old World bluestem response to fire and nitrogen fertilizers. J. Range Manage. 46:421.

Berg, W. A., and P. L. Sims. 1995. Nitrogen fertilizer use efficiency in steer gain on Old World bluestem. J. Range Manage. 48:465.

Bodine, T. N., H. T. Purvis III, and D. M. Engle. 2001. Response of Old World and little bluestem to a spring prescribed fire. Proc. Western Sect. Am. Soc. Anim. Sci. 52:451.

Bremner, J. M., and G. A. Breitenbeck. 1983. A simple method for determination of ammonium in semimicro-Kjeldahl analysis of soils and plant materials using a block digester. Commun. Soil Sci. Plant Anal. 14:905.

Celarier, R. P., and J. R. Harlan. 1958. The cytogeography of the Bothriochloa ischaemum complex. Gramineae. I. Taxonomy, and geographic distribution. Bot. J. Linn. Soc. 55:755.

Dewald, C. L., P. L. Sims, W. A. Berg, and L. M. White. 1988. Registration of 'WWIron Master' Old World bluestem. Crop Sci. 28:189.

Dewald, C. L., P. L. Sims, P. I. Coyne, and W. A. Berg. 1985. Registration of 'WW-Spar' bluestem. Crop Sci. 25:707.

Engle, D. M., and T. G. Bidwell. 2001. The response of central North American prairies to seasonal fire. J. Range Manage. 54:2.

Fuhlendorf, S. D., D. M. Engle, D. C. Arnold, and T. G. Bidwell. 2002. Influence of herbicide application on forb and arthropod communities of North American tallgrass prairies. Agric. Ecosyst. Environ. 92:251.

Fuhlendorf, S. D., D. M. Engle, C. M. O'Meilia, J. R. Weir, and D. C. Cummings. 2009. Does herbicide weed control increase livestock production on non-equilibrium rangeland? Agric. Ecosyst. Environ. 132:1.

Fuhlendorf, S. D., and F. E. Smeins. 1996. Spatial scale influence long-term temporal patterns of a semi-arid grassland. Landscape Ecol. 11:107.

Fuhlendorf, S. D., and F. E. Smeins. 1999. Scaling effects of grazing in a semi-arid grassland. J. Veg. Sci. 10:731.

Gunter, S. A., M. L. Galyean, and F. T. McCollum III. 1995a. Estimating ruminal nitrogen-to-energy balance with in situ disappearance data. J. Range Manage. 48:448.

Gunter, S. A., F. T. McCollum III, and R. L. Gillen. 1997. Forage intake by and site and extent of digestion in beef cattle grazing midgrass prairie rangeland and Plains bluestem pasture throughout the summer. J. Anim. Sci. 75:490.

Gunter, S. A., F. T. McCollum III, R. L. Gillen, and L. J. Krysl. 1995b. Diet quality and ruminal digestion in beef cattle grazing midgrass prairie rangeland or Plains bluestem pasture throughout the summer. J. Anim. Sci. 73:1174.

Hobbs, N. T., and D. S. Shimel. 1983. Fire effects on nitrogen mineralization and fixation in mountain shrub and grassland communities. J. Range Manage. 37:402.

Hodges, M., and T. G. Bidwell. 1993.

Production and Management of Old World Bluestems. Coop. Ext. Ser. Fact Sheet No. 3020, Oklahoma State Univ., Stillwater.

Hogan, J. P., and R. H. Weston. 1970. Quantitative aspects of microbial protein synthesis in the rumen. p. 474 in Physiology of Digestion and Metabolism in the Ruminant. A. T. Phillipson, ed. Oriel Press Ltd., Newcastle, UK.

Johnstone-Wallace, D. B., and K. Kennedy. 1944. Grazing management practices and their relationship to the behavior and grazing habits of cattle. J. Agric. Sci. (Camb.) 34:190.

McCollum, F. T., D. M. Engle, and J. F. Stritzke. 1992. Cattle performance following prescribed burning of rangeland in northcentral Oklahoma. p. 447 in Anim. Sci. Res. Rep., Oklahoma Agric. Exp. Sta. MP-136, Stillwater.

McIlvain, E. H., and M. C. Shoop. 1962. Daily versus every-third-day versus weekly feeding of cottonseed cake to beef steers on winter range. J. Range Manage. 15:143.

Moore, J. E., M. H. Brant, W. E. Kunkle, and D. I. Hopkins. 1999. Effects of supplementation on voluntary forage intake, diet digestibility, and animal performance. J. Anim. Sci. 77(Suppl. 2):122.

Morrow, L. A., and M. K. McCarthy. 1976. Effect of weed control on forage production in the Nebraska sandhills. J. Range Manage. 29:140.

New, M. G. 1997. Survey of weed management practices in pastures and rangelands in Oklahoma and selectivity of various herbicide treatments on cultivars of forage bermudagrass (Cynodon dactylon). MS Thesis. Oklahoma State Univ., Stillwater.

Nocek, J. E., and J. B. Russell. 1988. Protein and energy as an integrated system. Relationship of ruminal protein and carbohydrate availability to microbial synthesis and milk production. J. Dairy Sci. 71:2070.

NRCS. 2008. Web soil survey. USDA, Natural Resources and Conservation Service. Accessed Mar. 16, 2009. http://websoilsurvey.nrcs. usda.gov/app/HomePage.htm.
Philipp, D., V. G. Allen, R. J. Lascano, C. P. Brown, and D. B. Wester. 2007. Production and water use efficiency of three Old World bluestems. Crop Sci. 47:787.

Philipp, D., V. G. Allen, R. B. Mitchell, C. P. Brown, and D. B. Wester. 2005. Forage nutritive value and morphology of three Old World bluestems under a range of irrigation levels. Crop Sci. 45:2258.

Redmann, R. E. 1991. Nitrogen losses to the atmosphere from grass fire in Saskatchewan, Canada. Int. J. Wildland Fire 1:239.

Rice, C. K., and J. F. Stritzke. 1989. Effects of 2,4-D and atrazine on degraded Oklahoma grasslands. J. Range Manage. 42:217.

Shoop, M. C., and E. H. McIlvain. 1971. Efficiency of combining improvement practices that increase steer gains. J. Range Manage. 24:113.

Springer, T. L. 2007. Does weeping lovegrass maintain its crude protein content at the expense of its neighbors? Proc. Am. Forage Grassl. Coun., State College, PA. Accessed Mar. 6, 2010. http://websoilsurvey.nrcs.usda. gov/app/HomePage.htm.

Steel, R. G. D., and J. H. Torrie. 1980. Principles and Procedures of Statistics. McGrawHill Book Co., New York.

Taliaferro, C. M., J. R. Harlan, and W. L. Richardson. 1972. Plains Bluestem. Oklahoma Agric. Exp. Sta. Bull. B-966, Oklahoma State Univ., Stillwater.

Teague, W. R., S. L. Dowhower, W. E. Pinchak, D. R. Tolleson, and L. J. Hunt. 1996. Increasing utilization efficiency of continuously stocked Old World bluestem pasture. J. Range Manage. 49:535.

Thilenius, J. F., G. R. Brown, and C. C. Kaltenbach. 1975. Treating forb-dominated subalpine range with 2,4-D: Effects on herbage and cattle diets. J. Range Manage. 28:311.

Tilley, J. M. A., and R. A. Terry. 1963. A two stage technique for the in vitro digestion of forage crops. J. Br. Grassl. Soc. 18:104.

Towne, G., and C. Owensby. 1984. Long-term effects of annual burning at different dates in ungrazed Kansas tallgrass prairie. J. Range Manage. 37:392.

White, L. M., and C. L. Dewald. 1988. Leafstem ratio effect on forage quality of eight Old World bluestems. Soc. Range Manage., Ann. Mtg., Corpus Christie, TX. No. 341 (Abstr.).

White, L. M., and C. L. Dewald. 1996. Yield and quality of WW-Iron Master and Caucasian bluestem regrowth. J. Range Manage. 49:42.

White, L. M., G. P. Hartmen, and J. W. Bergman. 1981. In vitro digestibility, crude protein, and phosphorus content of straw of winter wheat, spring wheat, barley, and oat cultivars in eastern Montana. Agron. J. $73: 117$. 